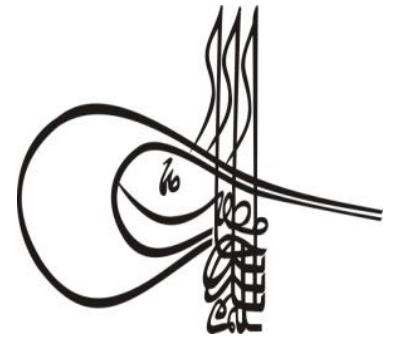

Received/Geliș: 26.08 .2019
Tutkish Studies

Social Sciences

Volume 14 Issue 5, 2019, p. 1993-2010

DOI: 10.29228/TurkishStudies.32665

ISSN: 2667-5617

Skopje/MACEDONIA-Ankara/TURKEY

Research Article / Araştırma Makalesi

Article Info/Makale Bilgisi

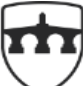

INTERNATIONAL

BALKAN

UNIVERSITY

EXCELLENCE FOR THE FUTURE IBU.EDU.MK

ar Report Dates/Rapor Tarihleri: Referee 1 (18.09.2019)-Referee 2 (02.10.2019)

This article was checked by iThenticate.

\title{
AVRUPA BİRLİĞİ'NDEN VAZGEÇMEK: TARİHSEL VE EKONOMİK BİR YAKLAŞIM
}

\author{
Ferhat APAYDIN* - Samet ZENGINOĞLU $U^{* *}$
}

\begin{abstract}
Öz
Türkiye'nin Avrupa özelinde Batı ile olan ilişkileri tarihsel bağlamda birçok tartışmanın konusunu oluşturmuştur. Tarihsel boyutta Batılılaşma/modernleşme olarak tanımlanabilen bu süreç, 20. yüzyılın ikinci yarısından bugüne Türkiye'nin Avrupa Birliği (AB) ile olan ilisskilerinde de çeşitli yansımalara sahiptir. $\mathrm{Bu}$ yansımalar kapsamında ilişkilerin tarihsel, sosyo-kültürel, ekonomik, politik, kurumsal ve hukuki faktörler gibi birçok perspektife sahip olduğu bilinmektedir. Bu çalıșma da özellikle tarihsel ve ekonomik perspektif kapsamında Türkiye-AB ilişkilerinin süreklilik ve bağımlılık boyutunu analiz etmek amacını taşımaktadır. Çalışmanın odağı Türkiye-AB ilişkileri ve bu ilişkilerdeki tarihsel süreklilik ve ekonomik bağımlılık üzerinedir. Gerek tarihsel gerekse ekonomi-politik olarak bir durum analizi yapılmıştır. Özellikle Türkiye-AB ilişkilerinde belli dönüm noktalarındaki söylemler ve reel durum dikkate alınmıştır. Makalede olas1 bir üyelik durumunda ortaya ç1kabilecek olan avantaj ve dezavantajlardan çok reel dünyada sürecin bir bağımlılık yarattığı üzerinde durulmaktadır. Öncelikle çalışmada Türkiye-AB ilişkilerinin tarihsel zeminde ekonomi politiği tartışılmıştır. Sonra ekonomik veriler temel alınarak karşılaştırmalı tablo ve grafikler kullanılarak tarihsel perspektif desteklenmiştir. $\mathrm{Bu}$ bağlamda özellikle Türkiye ve $A B$ arasındaki ticaret verileri üzerinde durulmuştur. $\mathrm{Bu}$ verilerden hareketle uzun dönemde ekonomik bir bağımlılık söylemi daha güçlü hale gelmiştir. Neticede AB ile ilişkilerin askıya alınması veya tamamen
\end{abstract}

Öğr. Gör., Adıyaman Üniversitesi, Sosyal Bilimler Meslek Yüksekokulu, Dış Ticaret Bölümü, E-posta: fapaydin@adiyaman.edu.tr

** (D) Öğr. Gör. Dr., Adıyaman Üniversitesi, Sosyal Bilimler Meslek Yüksekokulu, Dıı̧ Ticaret Bölümü, E-posta: sametzenginoglu@gmail.com 
koparılması söylemlerinin tarihsel ve ekonomik olarak kısa ve orta vadede kuvvetli bir olasılık taşımadiğı sonucuna ulaşılmıştır. Çalışmayla Türkiye-AB ilişkileri üzerine alternatif bir bakış sunularak literatüre katkı sağlamak amaçlanmaktadır.

Anahtar Kelimeler: Türkiye, Avrupa Birliği, Ekonomi, D1ş Ticaret.

\title{
GIVING UP THE EUROPEAN UNION: A HISTORICAL AND ECONOMIC APPROACH
}

\begin{abstract}
Turkey's relations with the West, with respect to Europe, have become a matter of several discussions in the historical context. The process, which could be defined as Westernization/modernizing in the historical context, has had various reflections on Turkey's relations with the European Union (EU) from the second half of $20^{\text {th }}$ century until today. Within the scope of these reflections, relations are known to have several perspectives like the historical, socio-cultural, economic, political, corporate and legal factors. This study aims to analyse the continuity and dependency dimension of the relations between Turkey and the EU, particularly wthin the framework of the historical and economic perspective. The focus of this study is on the Turkey-EU relations and on economic dependency and historical continuity in these relations. A situation analysis is conducted both in historical and economic-political terms. Certain statements in the turning point in Turkey-EU relations and real situation are particularly considered. In this article, it is emphasized that the process creates a dependency in the real world rather than the advantages and disadvantages of a possible membership. Principally, the political economy of Turkey-EU relations are discussed on a historical basis in the study. Then, historical perspective is supported by using comparative tables and graphs based on economic data. In this context, especially the article focuses on trade data between Turkey and the EU. Considering these data, a discourse of economic dependence in the long term is settled stronger case. As a result, it has been concluded that the discourse of suspending or completely breaking relations with the EU is not historically and economically strong possibility in the short and medium term. With this article, by presenting an alternative view on the Turkey-EU relations, it is intended to contribute to the literature.
\end{abstract}

\section{STRUCTURED ABSTRACT}

Turkey has left more than half a century on its way to the European Union. During this time, the relations have followed an unstable course due to various factors. For example, military interventions in Turkey and the economic depressions that emerged have increased the Union's criticism of Turkey and brought the relations to a deadlock at certain times. In addition to that, EU member states have been able to develop some negative statements about Turkey's accession process due to domestic political concerns. As expressed in the introduction section, in the face of this picture, there 
were also statements from Turkey that it could end the relations and that it was not without alternatives. However, the idea that the TurkeyEU relations are not likely to end depending on the developments related to the conjuncture appears to be the strongest possibility. As a matter of fact, as it has been observed in the scope of the study, it is not wrong to say that the relations are pursued in the supervision of governments, but nevertheless, continue - as a process - as a state policy. From the application for joint membership to the Ankara Agreement, from the Additional Protocol to the application for full membership, from the Customs Union to the negotiations for full membership, it is possible to see this pursuit. The fact that the TurkeyEU relations historically date back to the past and somehow continues regardless of changes in both the system and governments provides evidence that these relations will continue in the future. In order to make this argument stronger, economic data are important as well as political statements.

It can be said that, over time, the Turkey-EU relations have a bumpy, and from time to time, unstable course due to cyclical developments. When this process is against Turkey, opinions and statements from Turkey criticizing the EU's attitudes and policies become the main topic of the agenda. During the periods when the relations follow a usual course, however, common opinions and statements emerge, emphasizing, and criticizing the EU, that Turkey should no longer be held in the "waiting room" in this process and even that the EU is not indispensable. In this study, the Turkey-EU relations and the historical and economic dependence on these relations were addressed. A situation analysis was conducted from both historical and economic/political perspectives. Comparisons were made especially by taking into account the statements and real situation at certain milestones in the Turkey-EU relations. It was emphasized in the article that the process created an addiction in the real world rather than the advantages and disadvantages that might arise in the case of a possible membership. The study consists of two main sections and a conclusion. The first section, which presents the historical approach, emphasizes the fact that Turkish modernization dates back to the end of the 17th century, and therefore, the pursuit of modernization/westernization has also continued with the Republic of Turkey. In this section, the economic policy is discussed on the historical ground of Turkey-EU relations. In the same section, the main breaking points and milestones in the Turkey-EU relations are discussed. At these points, certain moves of some of the parties and political actors in Turkish political history in order to advance the process are presented. In the second section analyzing the economic approach, the status of the parties is determined, especially in the context of export and import figures, and as a result of this determination, it is discussed whether EU is in an indispensable position in terms of foreign trade figures of Turkey. In order to support this and to explain the big picture in more detail, export and import data between Turkey and the EU were compared by taking into account certain periods according to the first five chapters. Thus, Turkey's foreign trade performance, especially exports, was evaluated against the EU. In this way, the historical perspective was supported by using comparative tables and graphs based on economic data. Put differently, the statement about the possibility of an economic 
dependence was further strengthened in the long term. In the conclusion section of the study, the general trend of Turkey-EU relations was demonstrated from an economic/political perspective and an overall evaluation was carried out with alternative recommendations. Consequently, it was concluded that the statements of suspension or complete severing of relations with the EU were not strongly possible in the short and medium term historically and economically.

The main argument of this study is that the possibility of giving up the EU for Turkey is very low in the short and medium term, given the political and economic factors. Therefore, it is thought that the statement of an anti-EU sentiment, which has risen from time to time, is largely related to the domestic political conjuncture or prestige. Other than that, the possibility of giving up the $\mathrm{EU}$ is not realistic from historical, political and economic perspectives. The future of the Turkey-EU relations is important based on the findings of this study. Based on past political and, especially, economic data, a possible breakdown of the Turkey-EU relations will negatively affect Turkey economically and politically. In today's world, countries compete with production and exports on the one hand, they compete with consumption and imports on the other. Whether needed or not, consumerism drifts countries as well as individuals to a more prestigious perception. Based on this proposition, it is generally accepted that the main factor determining the future of countries is the idea of creating a market. Therefore, Turkey should make significant breakthroughs to produce high value-added goods in order to find very safe and stable markets. Otherwise, its competitive position in the international arena will become unsustainable. In addition to that, it is essential that Turkey establishes and maintains good relations with other countries and groups, both economically and politically, without damaging the country's independence.

Keywords: Turkey, European Union, Economics, Foreign Trade.

\section{Giriş}

Türkiye-Avrupa Birliği ilişkilerine bakıldığı vakit, ilişkilerin inişli-çıkışlı ve dönem dönem de konjonktürel gelişmelerin etkisiyle istikrarsız bir seyre sahip olduğu belirtilebilir. $\mathrm{Bu}$ seyrin Türkiye'nin aleyhine olduğu durumlarda, Türkiye'den AB'nin tutum ve politikalarını eleştiren görüş ve söylemler gündeme gelmektedir. Bununla birlikte ilişkilerin olağan seyrinde devam ettiği dönemlerde de bu kez Türkiye'nin artık bu süreçte "bekleme odası"ndan çıkması gerektiği yönünde yine AB'yi eleştiren ve hatta $A B$ 'nin vazgeçilmez olmadığı yönünde benzer görüş ve söylemlerle de karşılaşılmaktadır. Örneğin bu sürecin bitirilmesine (www.dw.com, 2019), "varsa yoksa AB" denilmemesine (www.bbc.com, 2019) yönelik söylemlere şahit olunduğu gibi Türkiye'nin AB'ye mecbur ve muhtaç olmadığı (www.ntv.com.tr, 2019) yönünde de siyasi aktörlerin çıkışlarına şahit olunmaktadır. Hatta AB sürecine bir alternatif olarak Şanghay İşbirliği Örgütü'ne üyelik de gündeme getirilmektedir (www.trthaber.com, 2019).

$\mathrm{Bu}$ perspektifin haricinde $\mathrm{AB}$ sürecine tamamen karşı olan politik görüşler de mevcuttur (Ülger, 2017). AB sürecine karşı olan görüşlerin temellerini dini, politik ya da ekonomik zeminde inşa ettikleri görülmektedir. Örneğin dini zeminde AB'nin bir "Hıristiyan Kulübü” olduğu, politik zeminde AB'nin ulus-üstü yapısının Türkiye'nin ulusal çıkarlarına aykırı olduğu ve ekonomik zeminde de bir slogan şeklinde “AB'nin ortak, Türkiye'nin de pazar” olduğu yönünde argümanlar 
geliştirilebilmektedir. Bu genel çerçeveye karşın ilgili yaklaşımların ekonomi-politik perspektiften gerçekçi olmadığı düşünülmektedir. Nitekim bu çalışmanın temel savı politik ve ekonomik faktörler dikkate alındığında Türkiye için $\mathrm{AB}$ 'den vazgeçme ihtimalinin kısa ve orta vadede çok düşük olduğudur. Dolayısıyla dönem dönem yükselişe geçen $\mathrm{AB}$ karşıtlığı söyleminin büyük oranda iç politik konjonktür ile ilgili olduğu, bu durumun haricinde $\mathrm{AB}$ 'den vazgeçme ihtimalinin tarihsel, politik ve ekonomik perspektiflerden mümkün görünmediği düşünülmektedir.

Çalışma iki ana bölüm ve sonuçtan oluşmaktadır. Tarihsel yaklaşımı ortaya koyan birinci bölümde, Türk modernleşmesinin XVII. yüzyılın sonlarına değin uzandığı ve dolayısıyla Türkiye Cumhuriyeti ile de modernleşme/Batılılaşma sürekliliğinin devam ettiği tespiti vurgulanacaktır. Aynı bölümde, Türkiye-AB ilişkilerindeki temel kırılma ve dönüm noktaları ele alınacaktır. $\mathrm{Bu}$ noktalarda Türk siyasi tarihinde yer alan birçok partinin ve siyasi aktörün sürecin ilerlemesi noktasında bazı hamleleri ortaya konulacaktır. Ekonomik yaklaşımı analiz eden ikinci bölümde ise özellikle ihracat ve ithalat rakamları bağlamında tarafların durumu tespit edilecek ve bu tespit neticesinde Türkiye'nin dış ticaret rakamları açısından AB'nin göz ardı edilemez bir konumda olup olmadığı tartışılacaktır. Bunu desteklemek adına bu yaklaşımda tablonun daha detaylı aktarılabilmesi için Türkiye ile $\mathrm{AB}$ arasındaki ihracat ve ithalat verileri ilk beş fasıla göre belli dönemleri dikkate alarak karşılaştırılacaktır. Böylelikle Türkiye'nin dış ticaret özellikle de ihracat performansı $\mathrm{AB}$ karşısında değerlendirilecektir. Çalışmanın sonuç bölümünde Türkiye- $\mathrm{AB}$ ilişkilerinin genel eğilimi, ekonomi-politik perspektiften ortaya konulacak ve alternatif önerilerle genel bir değerlendirme yapılacaktır.

\section{Tarihsel Yaklașım}

Türkiye'nin Avrupa ile olan ilişkileri Avrupa Birliği üyelik süreci kapsamında yoğunluk kazanmış olsa da, gerek Avrupa tarihi gerekse de Türk tarihi açısından ilişkilerin başlangıcını IV. ve $V$. yüzyıllara değin götürebilmek mümkündür. Dolayısıyla ilişkiler Avrupa Birliği’nin oluşum sürecinden daha eskiye dayanmaktadır (Sandalcılar ve Erdoğan, 2017: 122-123). Yine yoğun bir biçimde Osmanlı İmparatorluğu döneminde de Avrupa ile ilişkilerin devam ettiği görülmüştür. Mardin'in ifadesi ile (2003: 9-10); Osmanlı İmparatorluğu, Batı uygarlığı adı verilebilecek bu kültür bütünüyle hiçbir zaman ilişkisini kesmemiştir. Bu ilişki süreci inişli çıkışlı bir seyir takip etmiştir. Bazı dönemlerde Osmanlı'nın Avrupa karşısında, bazı dönemlerde de Avrupa'nın Osmanlı karşısında politik, askeri, diplomatik ve ekonomik üstünlüğü söz konusu olmuştur.

Türk modernleşmesi/çağdaşlaşması/batılılaşması olarak nitelendirilen süreç ile birlikte de sonuçları bugüne dek uzanan yeni bir tarihî bağlamın başlangıcı müşahede edilmiştir (bkz. Berkes, 2019; Zürcher, 2018). Bu bağlamın başlangıcı olarak 1699 Karlofça Antlaşması gösterilebilir. Bu dönemden sonradır ki Osmanlı İmparatorluğu, Avrupa/Batı eksenli yenilikler doğrultusunda hamlelerini gerçekleştirmiştir. Bu hamlelerin temeli, Avrupa karşısında geriye düşülen ekonomik ve politik duruma son verilmesi amacını taşımıştır. Zira süreç, "modern" döneme uyum sağlamanın bir yolu ve yöntemi olarak değerlendirilmiştir. Batılılaşmanın modernleşme ile eş tutulması da (Kılıç, 2005: 103) tabiatıyla bu yönde bir etki ortaya çıarmıştır.

Bahsi geçen yeniliklerin etkisini ve yansımalarını belirgin bir biçimde askeri, hukuki ve eğitim alanlarında görebilmek mümkün olmuştur. Örneğin, daha XVIII. yüzyıl başlarında, Batı'nın askeri kurumlarının ve silah gücünün İmparatorluğa nasıl getirilebileceği önemli bir devlet sorunu olmuştur (Mardin, 2003: 10). Nitekim III. Selim ve II. Mahmud dönemlerinde askeri alanda gerçekleştirilen -deyim yerindeyse- reformlar, bu sürecin dikkat çekici gelişmeleridir. Hukuki alanda ise XIX. yüzyılda atılan adımlar ön plana çıkmıştır. Bu bağlamda, 1808 yılında imzalanan ve Padişahın yetkilerini sınırlayarak Ayan'a yetkiler tanıyan Sened-i İttifak, Avrupa hukukuna uyumun ilk örnekleri arasında sayılmıştır. Benzer şekilde, 1839 "Tanzimat Fermanı", 1856 "Islahat Fermanı" ile getirilen Meşrutiyet İdaresi, vatandaşlara eşit hak ve yükümlülükler getirmeyi, kısaca Avrupa hukukuna uyumu amaçlayan adımlar olmuştur (Bilici, 2013, 78). Bu iki alanın yanı sıra 
eğitim alanında da birçok dönemde modernleşme yönündeki girişimlerle ve adımlarla karşılaşılmıştır (bkz. Somel, 2010).

XVIII. yüzyıldan XX. yüzyıla uzanan dönemde, bahsi geçen alanlara dair Avrupa eksenli yenilikler bir süreklilik arz etmiştir. Nitekim Türkiye Cumhuriyeti ile birlikte de bu sürekliliğin devamı ile karşılaşıldığını belirtmek yanlış olmayacaktır. Öyle ki Türkiye Cumhuriyeti'nin kuruluş felsefesini inşa eden saç ayaklarından birisini Batıcılık teşkil etmiştir. Bu felsefe, II. Dünya Savaşı sonrası oluşan Soğuk Savaş döneminde de devam etmiştir. Öyle ki 1949 yılında Türkiye Avrupa Konseyi'ne üye olmuş ve 1952 yılında da NATO'ya (Kuzey Atlantik Antlaşması Örgütü) katılmıştır. Özellikle NATO üyeliğinin, iki kutuplu sistem içerisinde tercihin Batı bloğundan yana kullanıldığının bir göstergesi/yanıtı olduğu bilinmektedir. $\mathrm{Bu}$ siyasi ve askeri alandaki entegrasyonlara üyeliğin ardından 1959 yllına gelindiğinde ise Türkiye Avrupa'daki ekonomik entegrasyon hareketine ortak üyelik başvurusunda bulunmuştur. $\mathrm{Bu}$ entegrasyon hareketinin temelleri 9 Mayıs 1950 tarihindeki Schuman deklarasyonu ile atılmış ve uygulamaya 1951 yılında imzalanan Paris Antlaşması ile kurulan Avrupa Kömür ve Çelik Topluluğu (AKÇT) ile 1957 yılına imzalanan Roma Antlaşması ile kurulan Avrupa Ekonomik Topluluğu (AET) ve Avrupa Atom Enerjisi Topluluğu (AAET) ile aktarılmıştır.

Çalışmanın temel savı açısından, ilk başvuru dönemi olan 1959 yılında, Türkiye'nin AET'ye neden ortak üyelik başvurusunda bulunmuş olduğuna dair çeşitli cevaplar aranabilir. Bu bağlamda Tecer (2007: 163-164); "Türkiye hangi faktörlerin etkisiyle AET'ye ortaklık bağ1 kurmak için başvuruda bulunmuştur?” sorusuna karşılık şu yanıtları ortaya koymuştur:

- Sovyet Rusya'nın (SSCB) savaş sonrasında Doğu Avrupa'daki yayılmacı politikasının oluşturduğu güvenlik tehdidi,

-II. Dünya Savaşı sonrasında Batı Avrupa'nın o sıradaki önemli ekonomik, siyasi ve askeri amaçlı kuruluşlarında (OEEC-Avrupa Ekonomik İşbirliği Teşkilatı, Avrupa Konseyi ve NATO) yerini almış olan Türkiye'nin siyasi işbirliği ve bütünleşme nihai amacıyla 1957 yılında oluşturulan AET'ye de katılarak, Batılı kimliğini tüm dünyaya bir kez daha göstermek istemesi,

- Gümrük Birliğine dayalı bir ortaklık ilişkisi çerçevesinde Türkiye'nin toplam ihracatında o sırada yaklaşı \%35 yer tutan Topluluk ülkeleri ile diş ticareti daha da geliştirme amacı,

- Ortaklık ilişkisi ile AET'den önemli miktarda ve elverişli koşullarla "dış fon kaynă̆ı" sağlanabileceği beklentisi,

-15 Temmuz 1959'da AET'ye başvuruda bulunmuş olan Yunanistan'dan, Topluluk ile bütünleşme sürecinde geri kalmama düşüncesi.

$\mathrm{Bu}$ noktada ekonomik saikler ön plana çıkmış olsa da, süreci Türkiye'nin diğer Batı merkezli kuruluşlara (ifade edildiği üzere OEEC, Avrupa Konseyi, NATO) üyeliğinin bir devamı olarak da düşünmek gerekmektedir. Bununla birlikte yine ilk başvurunun ardından, ilişkileri tesis eden diğer dönemlerde de ilgili hükümetlerin süreci devam ettirmiş olduğunu ifade etmek yanlış olmayacaktır. Hatta denilebilir ki, seçimle gelen hükümetlerin haricinde 27 Mayıs 1960, 12 Mart 1971, 12 Eylül 1980 askeri müdahaleleri sonrasında da ilişkilerin devamı yönünde dönemin aktörlerince büyük oranda mutabakat sağlanmış olduğu ifade edilebilir (Çalış, 2004: 81, 156, 205). Örneğin 12 Eylül askeri darbesinin ardından Kenan Evren'in Türkiye'nin Avrupa Toplulukları ve Avrupa Konseyi gibi demokratik ülkelerin üyesi olduğu kuruluşlarla ilişkilerin mevcut anlaşmalar çerçevesinde yürüyeceğini ifade etmesi dikkat çekmektedir (Erhan ve Arat, 2009: 83). 
Tablo 1: Türkiye-Avrupa Birliği İlişskilerinde Temel Aşamalar

\begin{tabular}{|c|c|c|c|}
\hline Süreç & Tarih & Hükümetler & Bașbakan \\
\hline Ortak Üyelik Başvurusu & 31 Temmuz 1959 & Demokrat Parti & Adnan Menderes \\
\hline Ankara Anlaşması (İmza) & 12 Eylül 1963 & $\begin{array}{l}\text { Cumhuriyet Halk Partisi, } \\
\text { Yeni Türkiye Partisi, } \\
\text { Cumhuriyetçi Köyü Millet } \\
\text { Partisi }\end{array}$ & İsmet İnönü \\
\hline $\begin{array}{l}\text { Ankara Anlaşması } \\
\text { (Yürürlük) }\end{array}$ & 1 Aralık 1964 & $\begin{array}{l}\text { Cumhuriyet Halk Partisi, } \\
\text { Bağımsızlar }\end{array}$ & İsmet İnönü \\
\hline Katma Protokol (İmza) & 23 Kasim 1970 & Adalet Partisi & Süleyman Demirel \\
\hline Katma Protokol (Yürürlük) & 1 Ocak 1973 & $\begin{array}{l}\text { Adalet Partisi, Cumhuriyet } \\
\text { Halk Partisi, Milli Güven } \\
\text { Partisi, Bağımsızlar }\end{array}$ & Ferit Melen \\
\hline Tam Üyelik Başvurusu & 14 Nisan 1987 & Anavatan Partisi & Turgut Özal \\
\hline Gümrük Birliği (İmza) & 6 Mart 1995 & $\begin{array}{l}\text { Doğru Yol Partisi, } \\
\text { Sosyaldemokrat Halkçı } \\
\text { Parti }\end{array}$ & Tansu Çiller \\
\hline Gümrük Birliği (Yürürlük) & 1 Ocak 1996 & $\begin{array}{l}\text { Doğru Yol Partisi, } \\
\text { Cumhuriyet Halk Partisi }\end{array}$ & Tansu Çiller \\
\hline “Aday Ülke" İlanı & 10-11 Aralık 1999 & $\begin{array}{l}\text { Demokratik Sol Parti, } \\
\text { Milliyetçi Hareket Partisi, } \\
\text { Anavatan Partisi }\end{array}$ & Bülent Ecevit \\
\hline $\begin{array}{l}\text { Tam Üyelik } \\
\text { Müzakerelerinin Başlangıcı }\end{array}$ & 3 Ekim 2005 & Adalet ve Kalkınma Partisi & $\begin{array}{l}\text { Recep Tayyip } \\
\text { Erdoğan }\end{array}$ \\
\hline
\end{tabular}

Dolayısıyla $\mathrm{AB}$ sürecinin bir hükümet politikası ya da kısa vadeli bir politik hamle olarak değerlendirilmesi yanlış bir kanaat olarak değerlendirilmektedir. Nitekim Tablo 1 bu hususla ilgili olarak sağlıklı bir perspektifin ortaya konulmasında yardımcı olabilecektir. Türkiye-AB ilişkilerinin geçmişten bu yana yedi temel aşamayı geride bırakmış olduğu söylenebilir. Bunlardan ilki ifade edilen 1959 yllındaki ortak üyelik başvurusudur ki o dönem Başbakan Adnan Menderes'tir. Ardından Ankara Anlaşması'nın hem imza hem de yürürlük sürecinde İsmet İnönü ile karşılaşılmaktadır. 1960 öncesi iç politikada, Menderes ve İnönü’nün birçok konuda anlaşma sağlayamadıkları ve farklı perspektiflere sahip oldukları belirtilebilirse de bu süreç konusunda ileriye dönük ortak adımlar atmış oldukları görülmektedir. Katma Protokol'ün imza sürecinde ise Başbakan olarak Süleyman Demirel vardır. İmza sürecinin ardından Katma Protokol'ün yürürlüğe girmesi, Muhtıra sonrası ve Türk siyasetinde çok da istikrarın olmadığı bir dönemde 1973 yılının başlangıcında gerçekleşmiştir. 1973 yılı aynı zamanda 1996 yılında yürürlüğe girecek olan Gümrük Birliği’nin hukuken başlangıcını oluşturmaktadır. Zira Türkiye ve AB karşılıklı olarak sanayi mallarında gümrük vergilerinde indirime gitmişlerdir. Sanayi mallarında 22 yıllık bir tarife indirimini öngören 'geçiş dönemi'nin akabinde Gümrük Birliği fiilen yürürlüğe girmiştir (Hatipler, 2011: 21). Tam üyelik başvurusu ise 1987 yılında Turgut Özal'ın başbakanlı̆̆ı dönemindedir. Ardından ekonomik entegrasyon açısından büyük bir kırılma noktası teşkil eden Gümrük Birliği Kararı'dır ki bu kararın gerek imza gerekse de yürürlük sürecinde başbakan Tansu Çiller vardır. Bu gelişmelerle birlikte, Türkiye Aralık 1999'da "aday ülke" ilan edilmiştir ve bu dönemde Başbakan Bülent Ecevit'tir. Nihai aşamada tam üyelik müzakereleri de 3 Ekim 2005'te Recep Tayyip Erdoğan'ın başbakanlığı döneminde gerçekleşmiştir. Dolayısıyla burada anlatılmak istenen husus şudur: Türk siyasi hayatında ön plana çıkmış olan bütün aktörlerin AB'ye üyelik sürecine katkısı bulunmaktadır. Bununla birlikte, elbette koalisyon hükümetleri döneminde yer alan diğer partileri ve parti başkanlarını da göz ardı etmemek gerekmektedir. Politik yaklaşımın haricinde bir sonraki bölümde değerlendirilecek olan ekonomik yaklaşımda da benzer bir süreçle karşılaşmak mümkün olacaktır. Nitekim ortaya konulan ihracat ve ithalat oranları da bu durumu teyit etmektedir. 
Türkiye'nin yarım asırdır AB'ye toplam ihracatının ortalamas $\% 50$ 'nin üzerinde tespit edilmiştir ki 12 Eylül 1980 askeri darbe sonrası ilişkilerin kısa süreli gerginliğinin sonucu olarak 1981 ve 1982 y1llarındaki düşüş eğilimli göstergelerinin haricinde bu ortalamanın istikrarlı bir kapsama sahip olduğunu ifade etmek olasıdır.

\section{Ekonomik Yaklaşım}

Bu bölümde Türkiye'nin genel diş ticaret performansı ve özellikle AB ile olan dış ticareti karşılaştırmalı tablo ve grafik analizi yardımıyla değerlendirilmiştir. Öncelikle Türkiye'nin toplam ithalat, ihracat ve GSYH rakamları sunulmuş ve bunların AB içindeki payları araştırılmıştır. Daha sonra Türkiye'nin $\mathrm{AB}$ ile yaptı̆̆ 1 ihracat ve ithalat verileri fasıllar bağlamında ele alınmış, böylelikle Türkiye'nin dış ticaretteki rekabetçi pozisyonu değerlendirilmiştir. Neticede Türkiye'nin dış ticaretinde özellikle de ihracatında önemli bir pazar oluşturan AB ile ilişkilerin seyrinin ekonomik verilerle karşılaştırmalı analizi yapılmıştır.

Tablo 2: Türkiye'nin GSYH, Toplam İhracat, İthalat ve AB ile olan İhracat ve İthalat Rakamlar1 (1969-2018, Milyon Dolar)

\begin{tabular}{|r|r|r|r|r|r|}
\hline Yillar & $\begin{array}{c}\text { Toplam } \\
\text { İhracat }\end{array}$ & Toplam İthalat & AB'ye İhracat & AB'den İthalat & $\begin{array}{c}\text { GSYH (Cari } \\
\text { Fiyatlarla) }\end{array}$ \\
\hline $\mathbf{1 9 6 9}$ & 537 & 801 & 332 & 475 & 19,467 \\
\hline $\mathbf{1 9 7 0}$ & 588 & 948 & 353 & 520 & 17,087 \\
\hline $\mathbf{1 9 7 1}$ & 677 & 1,171 & 386 & 662 & 16,257 \\
\hline $\mathbf{1 9 7 2}$ & 885 & 1,563 & 488 & 926 & 20,431 \\
\hline $\mathbf{1 9 7 3}$ & 1,31 & 2,086 & 722 & 1,256 & 25,724 \\
\hline $\mathbf{1 9 7 4}$ & 1,53 & 3,778 & 872 & 1,997 & 35,600 \\
\hline $\mathbf{1 9 7 5}$ & 1,40 & 4,739 & 744 & 2,645 & 44,634 \\
\hline $\mathbf{1 9 7 6}$ & 1,96 & 5,129 & 1,140 & 2,742 & 51,280 \\
\hline $\mathbf{1 9 7 7}$ & 1,75 & 5,796 & 1,035 & 2,951 & 58,677 \\
\hline $\mathbf{1 9 7 8}$ & 2,28 & 4,599 & 1,393 & 2,377 & 65,147 \\
\hline $\mathbf{1 9 7 9}$ & 2,26 & 5,069 & 1,341 & 2,621 & 89,394 \\
\hline $\mathbf{1 9 8 0}$ & 2,91 & 7,909 & 1,668 & 3,146 & 68,789 \\
\hline $\mathbf{1 9 8 1}$ & 4,70 & 8,933 & 1,807 & 3,424 & 71,040 \\
\hline $\mathbf{1 9 8 2}$ & 5,74 & 8,843 & 2,089 & 3,089 & 64,546 \\
\hline $\mathbf{1 9 8 3}$ & 5,72 & 9,235 & 2,326 & 3,534 & 61,678 \\
\hline $\mathbf{1 9 8 4}$ & 7,13 & 10,757 & 3,071 & 4,161 & 59,990 \\
\hline $\mathbf{1 9 8 5}$ & 7,95 & 11,343 & 3,509 & 4,535 & 67,235 \\
\hline $\mathbf{1 9 8 6}$ & 7,45 & 11,105 & 3,560 & 5,292 & 75,728 \\
\hline $\mathbf{1 9 8 7}$ & 10,1 & 14,158 & 5,270 & 6,482 & 87,173 \\
\hline $\mathbf{1 9 8 8}$ & 11,6 & 14,335 & 5,618 & 6,731 & 90,853 \\
\hline $\mathbf{1 9 8 9}$ & 11,6 & 15,792 & 5,887 & 6,966 & 107,143 \\
\hline $\mathbf{1 9 9 0}$ & 12,9 & 22,302 & 7,485 & 10,597 & 150,676 \\
\hline $\mathbf{1 9 9 1}$ & 13,5 & 21,047 & 7,784 & 10,675 & 150,028 \\
\hline $\mathbf{1 9 9 2}$ & 14,7 & 22,871 & 8,477 & 11,514 & 158,459 \\
\hline $\mathbf{1 9 9 3}$ & 15,3 & 29,428 & 8,287 & 14,929 & 180,170 \\
\hline $\mathbf{1 9 9 4}$ & 18,1 & 23,270 & 9,408 & 11,655 & 130,690 \\
\hline $\mathbf{1 9 9 5}$ & 21,6 & 35,709 & 12,232 & 18,034 & 169,486 \\
\hline $\mathbf{1 9 9 6}$ & 23,2 & 43,627 & 12,590 & 24,349 & 181,476 \\
\hline $\mathbf{1 9 9 7}$ & 26,2 & 48,559 & 13,471 & 26,128 & 189,835 \\
\hline $\mathbf{1 9 9 8}$ & 26,9 & 45,921 & 14,837 & 25,297 & 275,769 \\
\hline $\mathbf{1 9 9 9}$ & 26,5 & 40,671 & 15,454 & 22,538 & 255,883 \\
\hline $\mathbf{2 0 0 0}$ & 27,7 & 54,503 & 15,688 & 28,552 & 272,980 \\
\hline $\mathbf{2 0 0 1}$ & 31,3 & 41,399 & 17,576 & 19,841 & 200,252 \\
\hline $\mathbf{2 0 0 2}$ & 36,0 & 51,554 & 20,458 & 25,698 & 238,428 \\
\hline $\mathbf{2 0 0 3}$ & 47,2 & 69,340 & 27,479 & 35,157 & 311,823 \\
\hline & & & & & \\
\hline
\end{tabular}




\begin{tabular}{|l|r|r|r|r|r|}
\hline $\mathbf{2 0 0 4}$ & 63,1 & 97,540 & 36,699 & 48,131 & 404,786 \\
\hline $\mathbf{2 0 0 5}$ & 73,4 & 116,774 & 41,527 & 52,781 & 501,416 \\
\hline $\mathbf{2 0 0 6}$ & 85,5 & 139,576 & 48,137 & 59,447 & 552,487 \\
\hline $\mathbf{2 0 0 7}$ & 107, & 170,063 & 60,746 & 68,472 & 675,770 \\
\hline $\mathbf{2 0 0 8}$ & 132, & 201,964 & 63,708 & 74,513 & 764,336 \\
\hline $\mathbf{2 0 0 9}$ & 102, & 140,928 & 47,227 & 56,616 & 644,640 \\
\hline $\mathbf{2 0 1 0}$ & 113, & 185,544 & 52,934 & 72,391 & 771,902 \\
\hline $\mathbf{2 0 1 1}$ & 134, & 240,842 & 62,588 & 91,439 & 832,524 \\
\hline $\mathbf{2 0 1 2}$ & 152, & 236,545 & 59,394 & 87,657 & 873,982 \\
\hline $\mathbf{2 0 1 3}$ & 151, & 251,661 & 63,038 & 92,457 & 950,579 \\
\hline $\mathbf{2 0 1 4}$ & 157, & 242,177 & 68,514 & 88,784 & 934,186 \\
\hline $\mathbf{2 0 1 5}$ & 143, & 207,234 & 63,998 & 78,681 & 859,797 \\
\hline $\mathbf{2 0 1 6}$ & 142, & 198,618 & 68,343 & 77,501 & 863,722 \\
\hline $\mathbf{2 0 1 7}$ & 156, & 233,800 & 73,906 & 85,205 & 851,549 \\
\hline $\mathbf{2 0 1 8}$ & 167, & 223,047 & 83,956 & 80,813 & 787,087 \\
\hline
\end{tabular}

Kaynak: (TÜİK, 2019a); (TÜİK, 2019b); (Hazine ve Maliye Bakanlığı, 2019); (WDI, 2019) verileri yardımıyla yazarlar tarafından düzenlenmiştir.

Tablo 2 Türkiye'nin 1969-2018 yılları arasındaki GSYH (Gayri Safi Yurtiçi Hasıla), toplam ihracat ve ithalat tutarlarını, Türkiye'nin AB'ye olan ihracat ve AB'den yaptığı ithalat tutarlarını göstermektedir. 1969 yılında Türkiye'nin toplam ihracatı 537 Milyon Dolar iken; AB'ye olan ihracatı 332 Milyon Dolar boyutundadır. 2018 yılına gelindiğinde Türkiye'nin toplam ihracatı yaklaşık 13 kat artarak 167,924 Milyon Dolara ulaşmıştır. Türkiye'nin AB'ye olan ihracatı ise 2018 yılında yaklaşık 253 kat artarak 83,956 Milyon Dolara ulaşmıştır. Türkiye'nin ihracatı 2008 küresel krizi gibi kırılmalar dışında sürekli olarak artmıştır. Ancak Türkiye'nin AB'ye olan ihracatında Türkiye'nin AB üyelik süreci, 1996 yılında yürürlüğe giren Gümrük Birliği, Türkiye ve AB'nin yaşadığı finansal krizler ve Türkiye $A B$ arasındaki politik sürece bağlı olarak dalgalanmaların daha fazla olduğu görülmektedir. Ne ki; sonuçta Türkiye'nin toplam ihracatı genişledikçe AB'ye olan ihracatı da belli ölçüde artarak devam etmektedir. Türkiye'nin toplam ithalatına bakılacak olursa 1969 y1lında 801 Milyon Dolar olan ithalat 2018 y1lında 223,047 Milyon Dolar olarak ortalama 278 kat artmıştır. Ancak tablo incelendiğinde ithalatın bazı yıllarda (2013 gibi) çok daha fazla arttı̆̆ görülebilmektedir. Türkiye'nin AB'den yaptığı ithalat rakamları incelendiğinde 1969 y1lında 475 Milyon Dolar olan tutar 2018 y1lında gelindiğinde ortalama 170 kat artarak 80,813 Milyon Dolara ulaşmıştır. Ancak bazı y1llarda AB'den yapılan ithalat aşırı dalgalı olmaktadır. Burada yine Türkiye'nin AB'ye olan ihracatının dalgalı oluşundaki benzer faktörler etkili olmaktadır. Ayrıca 2018 yılı özelinde bakıldığında Türkiye-AB arasındaki ticarette ilk defa Türkiye dış ticaret fazlası vermiştir. Sonuçta Türkiye'nin AB ile olan hem ihracatı hem de ithalatı önemli düzeyde artmaya devam etmektedir. Bu tutarların Türkiye'nin milli gelirini, ihracat ve ithalatını nasıl etkilediği tablo 3 yardımıyla açıklanacaktır. 
Tablo 3: AB ile Yapılan İhracatın Toplam İhracat ve GSYH İçindeki Payı ile AB ile Olan İthalatın Toplam İthalat İçindeki Payları (1969-2018, \%)

\begin{tabular}{|c|c|c|c|}
\hline Yıllar & $\begin{array}{c}\text { AB'ye Yapılan } \\
\text { İhracatın Toplam } \\
\text { İhracat İçindeki Payı }\end{array}$ & $\begin{array}{c}\text { AB'den Yapılan } \\
\text { İthalatın Toplam } \\
\text { İthalat İçindeki Payı }\end{array}$ & $\begin{array}{c}\text { AB'ye Yapılan } \\
\text { İhracatın GSYH } \\
\text { İçindeki Payı }\end{array}$ \\
\hline 1969 & 61,76 & 59,25 & 1,70 \\
\hline 1970 & 60,06 & 54,92 & 2,07 \\
\hline 1971 & 57,07 & 56,53 & 2,38 \\
\hline 1972 & 55,17 & 59,29 & 2,39 \\
\hline 1973 & 54,84 & 60,19 & 2,81 \\
\hline 1974 & 56,92 & 52,87 & 2,45 \\
\hline 1975 & 53,12 & 55,83 & 1,67 \\
\hline 1976 & 58,16 & 53,46 & 2,22 \\
\hline 1977 & 59,02 & 50,92 & 1,76 \\
\hline 1978 & 60,88 & 51,68 & 2,14 \\
\hline 1979 & 59,31 & 51,71 & 1,50 \\
\hline $\begin{array}{l}1980 \\
\end{array}$ & 57,32 & 39,78 & 2,42 \\
\hline 1981 & 38,43 & 38,33 & 2,54 \\
\hline 1982 & 36,35 & 34,93 & 3,24 \\
\hline 1983 & 40,62 & 38,27 & 3,77 \\
\hline 1984 & 43,05 & 38,68 & 5,12 \\
\hline 1985 & 44,09 & 39,98 & 5,22 \\
\hline 1986 & 47,74 & 47,66 & 4,70 \\
\hline 1987 & 51,72 & 45,79 & 6,05 \\
\hline 1988 & 48,17 & 46,95 & 6,18 \\
\hline 1989 & 50,64 & 44,11 & 5,49 \\
\hline 1990 & 57,76 & 47,52 & 4,97 \\
\hline 1991 & 57,26 & 50,72 & 5,19 \\
\hline 1992 & 57,61 & 50,34 & 5,35 \\
\hline 1993 & 54,00 & 50,73 & 4,60 \\
\hline 1994 & 51,96 & 50,08 & 7,20 \\
\hline 1995 & 56,53 & 50,50 & 7,22 \\
\hline 1996 & 54,21 & 55,81 & 6,94 \\
\hline 1997 & 51,30 & 53,81 & 7,10 \\
\hline 1998 & 55,01 & 55,09 & 5,38 \\
\hline 1999 & 58,13 & 55,41 & 6,04 \\
\hline 2000 & 56,48 & 52,39 & 5,75 \\
\hline 2001 & 56,09 & 47,93 & 8,78 \\
\hline 2002 & 56,73 & 49,85 & 8,58 \\
\hline 2003 & 58,15 & 50,70 & 8,81 \\
\hline 2004 & 58,10 & 49,34 & 9,07 \\
\hline 2005 & 56,52 & 45,20 & 8,28 \\
\hline 2006 & 56,28 & 42,59 & 8,71 \\
\hline 2007 & 56,63 & 40,26 & 8,99 \\
\hline 2008 & 48,25 & 36,89 & 8,34 \\
\hline 2009 & 46,24 & 40,17 & 7,33 \\
\hline 2010 & 46,48 & 39,02 & 6,86 \\
\hline 2011 & 46,39 & 37,97 & 7,52 \\
\hline 2012 & 38,96 & 37,06 & 6,80 \\
\hline
\end{tabular}

Turkish Studies - Social Sciences

Volume 14 Issue 5, 2019 


\begin{tabular}{|l|r|r|r|}
\hline $\mathbf{2 0 1 3}$ & 41,53 & 36,74 & 6,63 \\
\hline $\mathbf{2 0 1 4}$ & 43,47 & 36,66 & 7,33 \\
\hline $\mathbf{2 0 1 5}$ & 44,49 & 37,97 & 7,44 \\
\hline $\mathbf{2 0 1 6}$ & 47,95 & 39,02 & 7,91 \\
\hline $\mathbf{2 0 1 7}$ & 47,08 & 36,44 & 8,68 \\
\hline $\mathbf{2 0 1 8}$ & 50,00 & 36,23 & 10,67 \\
\hline
\end{tabular}

Kaynak: Tablo 2 verilerinden yararlanılarak yazarlar tarafından hesaplanmıştır.

Tablo 3'te AB ile olan ihracatın GSYH içindeki payı ve toplam ihracat içindeki payı ile birlikte AB'den yapılan ithalatın toplam ithalat içindeki payı incelenmektedir. Türkiye'nin AB'ye yaptığı ihracatın ülkenin toplam ihracat içindeki payı 1969 yılında yaklaşık \%62 seviyesindedir. Bu oran sürekli dalgalanmakla birlikte günümüzde ortalama $\% 50$ seviyelerinde seyretmektedir. Türkiye yarım asırdır toplam ihracatının ortalama \%52,08'sini AB'ye yapmıştır. Yani Türkiye 1969 yılından beri yaptığı tüm ihracatın yarısından fazlasını sadece AB'ye yapmaktadır. Türkiye'nin ihracatında $\mathrm{AB}$ çok büyük bir pazar oluşturmaktadır. Bu durum geçmişte böyle olduğu gibi gelecekte de bu şekilde devam edeceği noktasında kuşkuya yer yoktur. Kısaca Türkiye ihracat açısından $\mathrm{AB}$ pazarına önemli ölçüde bağımlıdır. AB'ye yapılan ihracatın GSYH içindeki payına bakıldığında 1969 yılında bu oran \%1,70 seviyesinde iken zaman içinde dalgalanmalarla birlikte günümüzde \%10 seviyelerine ulaşmıştır. Dolayısıyla 1969 yılından 2018 y1lına kadarki süreçte AB'ye yapılan ihracatın artıș oranı GSYH artış oranından daha fazla olmuştur. Zira bu oran zaman içinde artmıştır. Türkiye'nin GSYH rakamlarının arzu edilen ölçüde artmaması eleştiri konusu olmakla birlikte AB'ye yapılan ihracatın artışı üretim ve GSYH açısından olumlu bir gelişmedir. Keza AB'ye yapılan ihracat GSYH'nin \%10 gibi önemli bir seviyesine tekabül etmektedir. Böylece Türkiye'nin ihracat pazarı açısından AB'nin çok önemli bir yeri olduğu bir kez daha tescillenmiș olmaktadır. Diğer bir husus ise Türkiye'nin AB'den yaptığı ithalatın ülkenin toplam ithalatı içindeki payıdır. $\mathrm{Bu}$ oran dönemin başında tıpkı ihracatın payı gibi \%60'lar seviyesinde iken, zaman içinde dalgalanmalarla birlikte son dönemlerde bir miktar azalmıştır. Günümüzde bu oran yaklaşık \%40 seviyelerindedir. Türkiye yarım asırdır toplam ithalatının ortalama \%46,67'sini AB'den yapmıştır. Türkiye'nin ithalatında özellikle ara malların yoğunlukta olduğu bilinmektedir. Öyleyse AB Türkiye'nin ara mal ithalatının neredeyse yarısını karşılamaktadır. Türkiye ithal malları açısından da AB'ye önemli ölçüde bağımlıdır.

Gerek tablo 2, gerekse de tablo 3 için göze çarpan diğer bir önemli nokta ise 1996 y1lında yürürlüğe giren Gümrük Birliği’nin etkisidir. Görüldüğü üzere 1996 yılı sonrasında Türkiye ile AB arasındaki ticaret hacminde ciddi bir artış yaşanmamıştır. Çünkü Gümrük Birliği’nin öngördüğü sanayi malları ticaretinde engellerin kaldırılması 1973 yılından itibaren (22 yıllık geçiş dönemi) zaten uygulanmaktaydı. Dolayısıyla 1996 yılı sonrasında dramatik değișiklikler yașanmamıștır. Türkiye-AB arasındaki ticareti yapılan ürünlerin yoğunluğunun sanayi mallarında olması göz önüne alındığında bu görüş daha da güçlenmektedir. Kaldı ki, 1997 Asya krizi, 1998 Rusya krizi, 2001 Şubat krizi gibi gerek küresel gerekse yerel ekonomik ve politik sorunlar da Gümrük Birliği sonrası dönemde ticaret hacminin çok fazla artmamasına sebebiyet vermiştir. Özellikle kur değişiklikleri ihracat ve ithalatı önemli ölçüde etkilemektedir. Kısaca Gümrük Birliği ticaret hacminin artmasında tek etken değildir. Benzer şekilde tablo 6 ve tablo 7 incelendiğinde Türkiye$\mathrm{AB}$ arası ticarette fasıllar bazında da 1996 sonrasında önemli değişiklikler yaşanmamıştır. 
Şekil 1. AB ile Yapılan İhracatın Toplam İhracat ve GSYH İçindeki Payı ile AB ile Olan İthalatın Toplam İthalat İçindeki Paylarının Grafiği (1969-2018, \%)

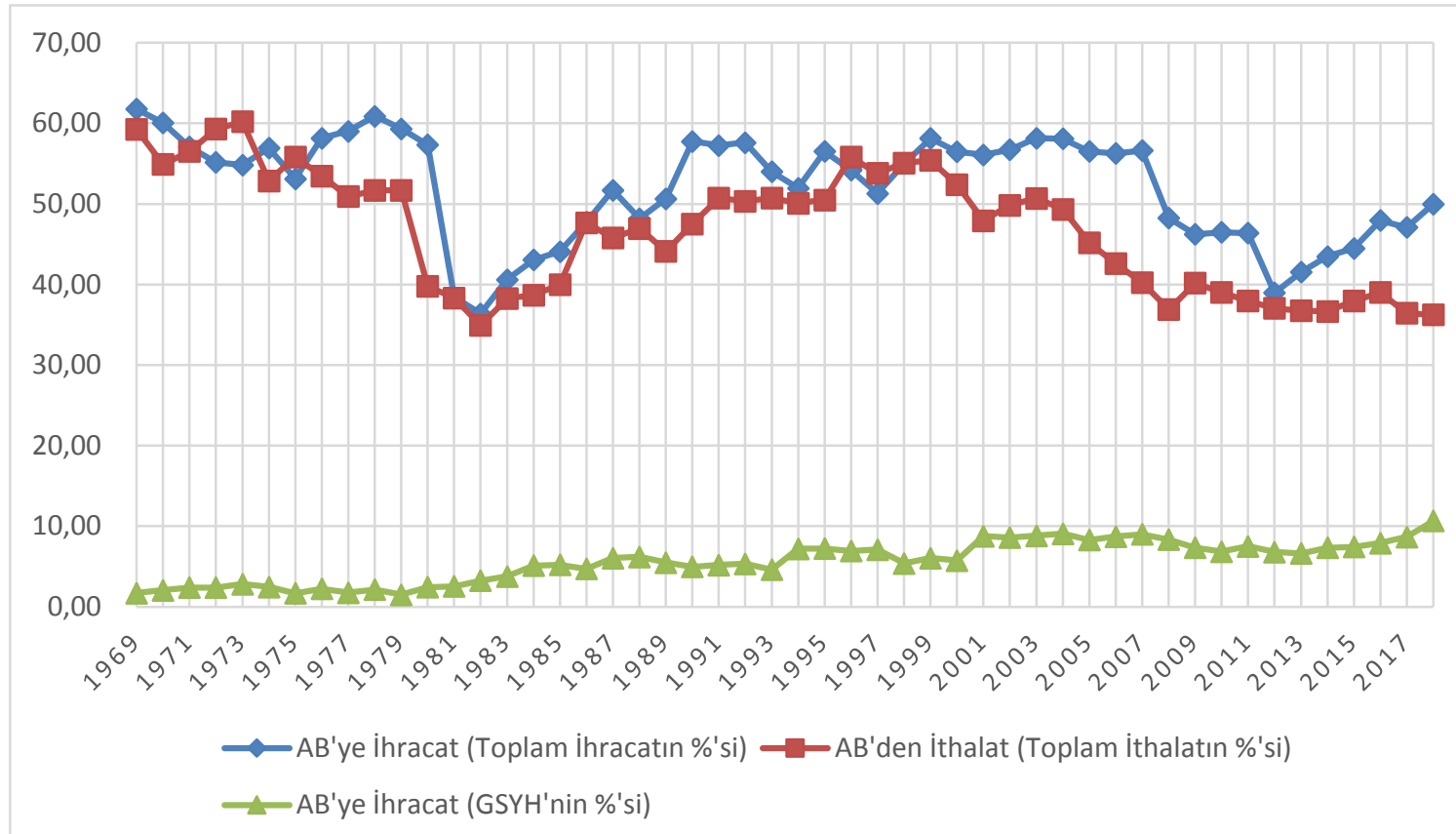

Kaynak: Tablo 3 verileri yardımıyla yazarlar tarafindan oluşturulmuştur.

AB ile yapılan ihracatın GSYH içindeki payı ve toplam ihracat içindeki payı ile birlikte $A B$ 'den yapılan ithalatın toplam ithalat içindeki paylarının daha iyi anlaşılması için şekil 1 daha net bir gözlem sunmaktadır. AB'ye yapılan ihracatın GSYH'ye oranını gösteren çizgi incelendiğinde sürekli bir artış olduğu net bir şekilde görülmektedir. Buradan çok net anlaşılmaktadır ki Türkiye'nin GSYH içinde AB'ye yaptığı ihracatın kayda değer bir önemi vardır. AB'ye yapılan ihracatın toplam ihracat içindeki payına bakıldığında bu çizgi çok değişken bir seyir izlemektedir. Aynı zamanda zaman içinde daima Türkiye'nin toplam ihracatında çok önemli bir yeri olduğu da aşikârdır. Bununla birlikte AB'den ithalat çizgisine bakıldığına bu çizgi genellikle AB'ye ihracat çizgisinin altında seyretmekle beraber bu iki eğri çoğu dönemde birlikte hareket etmektedir. Yani AB'ye yapılan ihracatın artması bir anlamda AB'den yapılan ithalata bağlı gözükmektedir. Bunun tam tersi de mümkün olmakla birlikte, Türkiye'nin ithalatının daha çok ara malları olduğu dikkate alınırsa ilk önermenin daha güçlü olabileceği düşünülebilir. Zira bunu test etmek için ekonomipolitik bir değerlendirmeyi konu alan bu çalışmada ekonometrik bir analiz yöntemine başvurulmayacaktır. Çünkü çalışmanın odağı ihracat ile ithalat arasındaki ilişki değildir. Ancak AB ile yapılan ihracat ve ithalatın daha detaylı bir fotoğrafı aşağıdaki tablolarda görülmektedir. Neticede gerek AB'den yapılan ithalat, gerekse AB'ye yapılan ihracat Türkiye'nin toplam ithalat ve ihracatında göz ardı edilemeyecek ölçüde önemli bir yere sahiptir.

Türkiye ile $\mathrm{AB}$ arasında yapılan ticarette Türkiye'nin rekabetçi pozisyonunun değerlendirilmesi açısından aşağıdaki tablolar daha detaylı bilgiler sunmaktadır. Tablo 4 Türkiye'nin AB ile yaptığı 1979 yılındaki ilk beş ihracat ve ithalat fasıllarını karşılaştırmalı olarak vermektedir. 1979 yılının seçilmesinin sebebi Türkiye'de uygulamaya konulan 24 Ocak 1980 Kararlarının öncesi ile sonrası arasında karşılaştırma yapılabilmesi içindir. Tablo 4'te görüldüğü üzere 1979 yılında Türkiye'nin AB'ye yaptığı ihraç malları daha çok katma değeri düşük emekyoğun (daha çok gıda-tarım, tekstil gibi) mallardır. Aynı yıl AB'den yapılan ithalata bakıldığında ise ara malları ve sermaye malları daha yoğunluktadır. Öyleyse Türkiye ithal ikameci kalkınmanın 
ilk aşaması olan temel tüketim mallarının ülke içinde üretilip, ara ve sermaye (veya yatırım) mallarının ithal edilmesi sürecine uygun bir diş ticaret süreci içindedir.

Tablo 4: Fasıllara Göre 1979 Y11 Türkiye-AB İhracat ve İthalat (Milyon Dolar)

\begin{tabular}{|c|l|r|r|l|r|}
\hline Fasıl & \multicolumn{1}{|c|}{ Fasıl Adı } & İhracat & Fasıl & \multicolumn{1}{|c|}{ Fasıl Adı } & İthalat \\
\hline $\mathbf{8}$ & $\begin{array}{l}\text { Yenilen meyve, kavun ve } \\
\text { turunçgillerin kabukları }\end{array}$ & 435 & $\mathbf{8 4}$ & $\begin{array}{l}\text { Makinalar, mekanik cihazlar, } \\
\text { kazanlar ve aksam, parçalar }\end{array}$ & 654 \\
\hline $\mathbf{5 5}$ & Pamuk & 353 & $\mathbf{2 7}$ & $\begin{array}{l}\text { Madeni yakıtlar, yağlar vb. } \\
\text { müstahsallar }\end{array}$ & 515 \\
\hline $\mathbf{2 5}$ & $\begin{array}{l}\text { Tuz, kükürt, toprak ve taslar, } \\
\text { alçılar ve çimento }\end{array}$ & 71 & $\mathbf{8 7}$ & $\begin{array}{l}\text { Kara taşıtları ve bunların aksam, } \\
\text { parçaları }\end{array}$ & 207 \\
\hline $\mathbf{2 4}$ & $\begin{array}{l}\text { Tütün ve tütün yerine geçen } \\
\text { işlenmiş maddeler }\end{array}$ & 62 & $\mathbf{7 3}$ & Dökme demir/demir ve çelik & 202 \\
\hline $\mathbf{6 1}$ & $\begin{array}{l}\text { Mensucattan giyim eşyası ve } \\
\text { teferruatı }\end{array}$ & 42 & $\mathbf{8 5}$ & $\begin{array}{l}\text { Elektrikli makina ve cihazlar, } \\
\text { aksam ve parçaları }\end{array}$ & 172 \\
\hline
\end{tabular}

Kaynak: (TÜİK, 2019c) verilerinden yazarlar tarafindan düzenlenmiştir.

Tablo 5 aynı verileri 1985 yılı için özetlemektedir. 1985 yılı; gerek 24 Ocak Kararları, gerekse ihracata dayalı büyüme modelinin uygulamaya konmasının etkisini göstermesi açısından tesadüfi olarak tercih edilen bir yıldır. 1985 yılı ihracat açısından 1979 yılı ile karşılaştırıldığında fasıllar temelinde anlamlı bir değişmenin olmadığı görülmektedir. Yani emek yoğun mallar aynı şekilde Türkiye'nin AB'ye olan ihracatında önemli yer tutmaktadır.

Tablo 5: Fasıllara Göre 1985 Y11ı Türkiye-AB İhracat ve İthalat (Milyon Dolar)

\begin{tabular}{|c|l|r|r|l|r|}
\hline Fasıl & \multicolumn{1}{|c|}{ Fasıl Adı } & İhracat & Fasıl & \multicolumn{1}{|c|}{ Fasıl Adı } & İthalat \\
\hline $\mathbf{4 2}$ & $\begin{array}{l}\text { Deri/saraciye eşyası; mahfaza } \\
\text { teşkil eden eşyalar }\end{array}$ & 437 & $\mathbf{8 4}$ & $\begin{array}{l}\text { Makinalar, mekanik cihazlar, } \\
\text { kazanlar ve aksam, parçalar }\end{array}$ & 1,012 \\
\hline $\mathbf{5 5}$ & Pamuk & 390 & $\mathbf{7 3}$ & Dökme demir/demir ve çelik & 668 \\
\hline $\mathbf{8}$ & $\begin{array}{l}\text { Yenilen meyve, kavun ve } \\
\text { turunçgillerin kabukları }\end{array}$ & 332 & $\mathbf{8 5}$ & $\begin{array}{l}\text { Elektrikli makina ve cihazlar, } \\
\text { aksam ve parçaları }\end{array}$ & 362 \\
\hline $\mathbf{6 1}$ & $\begin{array}{l}\text { Mensucattan giyim eşyası ve } \\
\text { teferruatı }\end{array}$ & 329 & $\mathbf{2 0}$ & Organik kimyasal ürünler & 325 \\
\hline $\mathbf{6 0}$ & Örme eşya & 266 & $\mathbf{8 7}$ & $\begin{array}{l}\text { Kara taşıtları ve bunların aksam, } \\
\text { parçaları }\end{array}$ & 320 \\
\hline
\end{tabular}

Kaynak: (TÜIKK, 2019c) verilerinden yazarlar tarafindan düzenlenmiştir.

1985 yılına AB'den yapılan ithal malları açısından bakıldığında (tablo 5) ilk beş fasılda neredeyse 1979 yılının aynı ürünleri yer almaktadır. Türkiye AB'den katma değeri yüksek ara ve sermaye malları ithal etmeye devam etmektedir. Daha önceki tablolarda aktarıldığı üzere AB ile olan gerek ihracat gerekse de ithalat verileri Türkiye'nin toplam dış ticaretinde çok önemli bir yer tutmaktadir. 


\begin{tabular}{|c|c|c|c|c|c|}
\hline Fasıl & Fasıl Adı & İhracat & Fasıl & Fasıl Adı & İthalat \\
\hline 61 & $\begin{array}{l}\text { Örme giyim eşyası ve } \\
\text { aksesuar1 }\end{array}$ & 2,721 & 39 & Plastikler ve mamulleri & 1,052 \\
\hline 62 & $\begin{array}{l}\text { Örülmemiş giyim eşyası ve } \\
\text { aksesuarı }\end{array}$ & 1,588 & 72 & Demir ve çelik & 1,593 \\
\hline 8 & $\begin{array}{l}\text { Yenilen meyvalar ve yenilen } \\
\text { sert kabuklu meyvalar }\end{array}$ & 976 & 84 & $\begin{array}{l}\text { Kazanlar, makinalar, } \\
\text { mekanik cihazlar ve aletler, } \\
\text { nükleer reaktörler, bunların } \\
\text { aksam ve parçaları } \\
\end{array}$ & 4,025 \\
\hline 85 & $\begin{array}{l}\text { Elektrikli makina ve cihazlar, } \\
\text { ses kaydetme-verme, } \\
\text { televizyon görüntü-ses } \\
\text { kaydetme-verme cihazları, } \\
\text { aksam-parça-aksesuarı }\end{array}$ & 617 & 85 & $\begin{array}{l}\text { Elektrikli makina ve } \\
\text { cihazlar, ses kaydetme- } \\
\text { verme, televizyon görüntü- } \\
\text { ses kaydetme-verme } \\
\text { cihazları, aksam-parça- } \\
\text { aksesuarı }\end{array}$ & 1,573 \\
\hline 63 & $\begin{array}{l}\text { Dokunabilir maddelerden } \\
\text { hazır eşya, takımlar, } \\
\text { kullanılmış giyim ve } \\
\text { dokunmuş diğer eşya, } \\
\text { paçavralar }\end{array}$ & 405 & 87 & $\begin{array}{l}\text { Motorlu kara taşıtları, } \\
\text { traktörler, bisikletler, } \\
\text { motosikletler ve diğer kara } \\
\text { taşıtları, bunların aksam, } \\
\text { parça, aksesuarı }\end{array}$ & 1,153 \\
\hline
\end{tabular}

Kaynak: (TÜİK, 2019c) verilerinden yazarlar tarafından düzenlenmiştir.

1995 y1lı (tablo 6) da benzer şekilde aynı verileri ihtiva etmektedir. Burada 1995 yılının seçilmesinin sebebi 1996 yılında yürürlüğe giren Gümrük Birliği’nin Türkiye'nin ihracat performansına etkisini karşılaştırabilmektir. 1995 yılında ihracat açısından Türkiye yine 1985 yılına benzerlik göstermekle birlikte niteliksel olarak katma değeri yüksek ürünlere doğru az da olsa bir dönüşüm başarısı görünmektedir. 1995 yılı ithalat açısından değerlendirildiğinde Türkiye katma değeri yüksek malları ithal etmeye devam etmektedir. 
Tablo 7: Fasıllara Göre 1997 Yılı Türkiye-AB İhracat ve İthalat (Milyon Dolar)

\begin{tabular}{|c|c|c|c|c|c|}
\hline Fasıl & Fasıl Adı & İhracat & Fasıl & Fasıl Adı & İthalat \\
\hline 61 & $\begin{array}{l}\text { Örme giyim eşyası ve } \\
\text { aksesuarı }\end{array}$ & 2,973 & 84 & $\begin{array}{l}\text { Kazanlar, makinalar, mekanik cihazlar ve } \\
\text { aletler, nükleer reaktörler, bunların } \\
\text { aksam ve parçaları }\end{array}$ & 6,286 \\
\hline 62 & $\begin{array}{l}\text { Örülmemiş giyim eşyası } \\
\text { ve aksesuarı }\end{array}$ & 1,585 & 87 & $\begin{array}{l}\text { Motorlu kara taşıtları, traktörler, } \\
\text { bisikletler, motosikletler ve diğer kara } \\
\text { taşitları, bunların aksam, parça, aksesuarı }\end{array}$ & 3,017 \\
\hline 8 & $\begin{array}{l}\text { Yenilen meyvalar ve } \\
\text { yenilen sert kabuklu } \\
\text { meyvalar }\end{array}$ & 988 & 85 & $\begin{array}{l}\text { Elektrikli makina ve cihazlar, ses } \\
\text { kaydetme-verme, televizyon görüntü-ses } \\
\text { kaydetme-verme cihazları, aksam-parça- } \\
\text { aksesuarı }\end{array}$ & 2,689 \\
\hline 85 & $\begin{array}{l}\text { Elektrikli makina ve } \\
\text { cihazlar, ses kaydetme- } \\
\text { verme, televizyon } \\
\text { görüntü-ses kaydetme- } \\
\text { verme cihazları, aksam- } \\
\text { parça-aksesuarı }\end{array}$ & 905 & 39 & Plastikler ve mamulleri & 1,506 \\
\hline 63 & $\begin{array}{l}\text { Dokunabilir maddelerden } \\
\text { hazır eşya, takımlar, } \\
\text { kullanılmış giyim ve } \\
\text { dokunmuş diğer eşya, } \\
\text { paçavralar }\end{array}$ & 572 & 72 & Demir ve çelik & 1,398 \\
\hline
\end{tabular}

Kaynak: (TÜİK, 2019c) verilerinden yazarlar tarafından düzenlenmiştir.

1997 yılı incelendiğinde ihracat açısından 1996 Gümrük Birliği’nin etkisinin gerek fasıl bazında gerekse toplam ihracat bedeli temelinde önemli bir değişiklik yaratmadığı ortadadır. Daha önce de ifade edildiği üzere çeşitli sebeplerden dolayı 1996 sonrasında gerek ticaret hacmi gerekse katma değeri yüksek ürünlere geçiş yaşanamamıştır. Tablo 7'de görüldügü üzere fasıllar tamamen aynıdır. Türkiye AB'ye emek-yoğun malların yanı sıra 1995 yılı ile kıyaslandığında çok az da olsa daha yüksek katma değer yaratan ürünler ihraç etmeye devam etmektedir. Türkiye-AB arasındaki ticaret ağırlıklı olarak sanayi malları üzerinedir. Bunun sebebi geçiş döneminin başladığı 1973 yılı itibariyle sanayi mallarında Türkiye-AB arasında karşılıklı olarak tarifelerin sıfırlanmasıdır. 


\begin{tabular}{|c|c|c|c|c|c|}
\hline \multicolumn{6}{|c|}{ Tablo 8: Fasıllara Göre 2018 Y1lı Türkiye-AB İhracat ve İthalat (Milyon Dolar) } \\
\hline Fasıl & Fasıl Adı & İhracat & Fasil & Fasıl Adı & İthalat \\
\hline 87 & 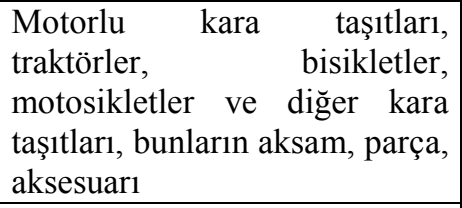 & 21,004 & 84 & $\begin{array}{l}\text { Kazanlar, makinalar, mekanik } \\
\text { cihazlar ve aletler, nükleer } \\
\text { reaktörler, bunların aksam ve } \\
\text { parçaları }\end{array}$ & 14,458 \\
\hline 84 & $\begin{array}{l}\text { Kazanlar, makinalar, mekanik } \\
\text { cihazlar ve aletler, nükleer } \\
\text { reaktörler, bunların aksam ve } \\
\text { parçaları }\end{array}$ & 8,171 & 87 & $\begin{array}{l}\text { Motorlu kara taşıtları, traktörler, } \\
\text { bisikletler, motosikletler ve diğer } \\
\text { kara taşıtları, bunların aksam, } \\
\text { parça, aksesuarı }\end{array}$ & 10,285 \\
\hline 61 & $\begin{array}{|lll|}\begin{array}{l}\text { Örme giyim eşyası ve } \\
\text { aksesuarı }\end{array} & \\
\end{array}$ & 6,720 & 72 & Demir ve çelik & 7,770 \\
\hline 72 & Demir ve çelik & 4,919 & 85 & $\begin{array}{l}\text { Elektrikli makina ve cihazlar, ses } \\
\text { kaydetme-verme, televizyon } \\
\text { görüntü-ses kaydetme-verme } \\
\text { cihazları,aksam-parça-aksesuarı }\end{array}$ & 5,766 \\
\hline 85 & $\begin{array}{l}\text { Elektrikli makina ve cihazlar, } \\
\text { ses kaydetme-verme, } \\
\text { televizyon görüntü-ses } \\
\text { kaydetme-verme } \\
\text { cihazları,aksam-parça- } \\
\text { aksesuarı }\end{array}$ & 4,804 & 39 & Plastikler ve Mamulleri & 5,690 \\
\hline
\end{tabular}

Kaynak: (TÜIK,, 2019c) verilerinden yazarlar tarafından düzenlenmiştir.

Son olarak tablo 8'de 2018 yılında Türkiye-AB ihracat ve ithalatının ilk beş faslın verileri yer almaktadır. 2018 yılına gelindiğinde Türkiye AB'ye yapılan ihraç malları açısından kısmen niteliksel bir dönüşüm yolunda başarı kat etmiştir. Şöyle ki, 1997 yılında AB'den ithal edilen ilk beş fasıldan dördünü şimdi Türkiye aynı ülke grubuna ihraç etmektedir. Dolaysıyla son dönemlerde Türkiye katma değeri kısmen yüksek ara ve yatırım malları ihracına yönelmiştir. Ancak aynı yı1 ithalat açısından değerlendirilirse 1997 yılında ithal edilen aynı fasıllar ithal edilmeye devam edilmektedir. Ancak burada dikkat edilmesi gereken diğer bir nokta, Türkiye ithal ettiği beş faslın dördünü yine AB'ye ihraç etmektedir. Bu durum son yıllarda Türkiye'nin ihracatının ithalata bağımlı olduğu olasılığını en azından bazı mal türlerinde daha güçlü hale getirmektedir. Bunun yanı sıra Türkiye ithalat açısından (özellikle ara malları) ihracat açısından da AB'ye ihtiyaç duymaktadır. Toplam ihracatının ortalama olarak yarısından fazlasını AB'ye gerçekleştirmektedir. Bu pazarın, $\mathrm{AB}$ ile ilişkilerin değerlendirilmesi konusunda göz ardı edilmemesi gerekmektedir.

\section{Sonuç}

Süreç ve süreklilik bağlamında Türkiye'nin AB ile ilişkilerini ilk başvurunun gerçekleştiği 1959 tarihinden başlatmak analizlerin eksik tespitler ortaya çıkarmasına neden olmaktadır. Türkiye'nin Batı ile ilişkilerinin yanı sıra Batılılaşma süreci Osmanlı İmparatorluğu'na dek uzanmaktadır. Türkiye'nin Soğuk Savaş dönemindeki iki kutuplu sistemde tercihini Batı'dan yana kullanmış olduğu bilinmektedir. Avrupa Konseyi, OECD (Ekonomik Kalkınma ve İşbirliği Örgütü), NATO üyeliklerinin yanı sıra AET'ye başvuru süreci bu tercihin en belirgin göstergelerini teşkil etmiştir. Bu çalışmada $\mathrm{AB}$-Türkiye ilişkilerinin geleceği, tarihi bir zeminde ekonomi-politik perspektiften tartışılmıştır. 
Türkiye, Avrupa Birliği yolunda yarım yüzyıldan uzun bir süreyi geride bırakmıştır. Bu zaman zarfında ilişkiler çeşitli faktörler sebebiyle istikrarsız bir seyir takip etmiştir. Örneğin, Türkiye'deki askeri müdahaleler ve ortaya çıkan ekonomik krizler, Birliğin Türkiye'ye yönelik eleştirilerini artırmış ve ilişkileri belli dönemlerde çıkmaza sokmuştur. Bunun yanı sıra AB üyesi ülkeler iç politik kaygılarla Türkiye'nin üyelik sürecine dair olumsuz söylemler geliştirebilmişlerdir. Bu tablo karşısında da giriş bölümünde ifade edildiği üzere, Türkiye'den ilişkileri bitirme ve AB'nin alternatifsiz olmadığı yönünde söylemlerle de karşılaşılmıştır. Ne var ki; Türkiye-AB ilişkilerinin konjonktüre bağlı gelişmelere göre sona erme ihtimalinin söz konusu olmadığı düşüncesi en güçlü olasılık olarak karşımıza çıkmaktadır. Nitekim çalışma kapsamında da müşahede edildiği üzere, ilişkilerin hükümetler nazarında yürütüldüğü ve fakat süreç olarak bir devlet politikası olarak devam ettiğini söylemek yanlış olmayacaktır. Ortak üyelik başvurusundan Ankara Anlaşması'na, Katma Protokol'den tam üyelik başvurusuna, Gümrük Birliği'nden tam üyelik müzakerelerine değin bu sürekliliği görmek mümkündür.

Tarihi süreç içinde Türkiye-AB ilişkilerinin çok eskiye dayanması ve gerek sistem, gerekse de hükümet değişikliklerinden bağımsız olarak bir şekilde devam etmesi bu ilişkilerin gelecekte de devam edeceğine kanıt oluşturmaktadır. Bu argümanı daha güçlü kılmak adına siyasi söylemlerin yanı sıra ekonomik veriler önem arz etmektedir. Ekonomik verilerden de anlaşılmaktadır ki Türkiye'nin AB'ye dış ticaret açısından önemli ölçüde bir bağımlılığı olduğu gibi AB'nin de Türkiye'ye kısmen bağımlılığı görülmüştür. Türkiye'nin ihracatı açısından AB büyük bir pazar oluşturmakla beraber Türkiye toplam ihracatının ortalama yarısından fazlasını AB ülkelerine yapmaktadır. Benzer şekilde ithalat, özellikle ara malları açısından yine AB'ye anlamlı düzeyde bir bağımlılık söz konusudur. Elbette $\mathrm{AB}$ de temel tüketim mallarını ucuza temin etmek gibi avantajlarla birlikte ihracatı açısından da kendisine bir pazar yaratmak adına bir ölçüde Türkiye'ye bağımlıdır. Öyleyse zaman içinde Türkiye-AB ilişkilerinin kesilmesi gibi siyasi söylemler ekonomik olarak desteklenmemektedir. Bu bağlamda bu politik söylemlerin daha çok iç politika argümanı olarak kullanıldığı sonucu daha muhtemel gözükmektedir.

Türkiye-AB ilişkilerinin geleceği bu çalışmanın tespitleriyle önem arz etmektedir. Geçmiş politik ve özellikle ekonomik verilerden hareketle Türkiye-AB ilişkilerin olası bir kopma durumu Türkiye'yi ekonomi-politik açıdan olumsuz etkileyecektir. Günümüz dünyasında ülkeler bir taraftan üretim ve ihracatla yarışırken, diğer yandan tüketimle ve ithalatla yarışmaktadır. İhtiyaç olsun olmasın tüketim çılgınlığ gerek bireyleri gerekse ülkeleri daha prestijli bir algiya sürüklemektedir. $\mathrm{Bu}$ önermeden yola çıkarak ülkelerin geleceğini belirleyen temel faktörün pazar yaratma düşüncesi olduğu kabul görmektedir. Öyleyse Türkiye çok güvenli ve istikrarlı pazarlar bulmak adına katma değeri yüksek mallar üretmek için önemli atılımlar yapmalıdır. Aksi durumda uluslararası alanda rekabetçi pozisyonu sürdürülemez hale gelecektir. Bunun yanı sıra ülke bağımsızlığı zedelenmeden Türkiye'nin gerek ekonomik gerekse politik anlamda diğer ülke ve gruplarla iyi ilişkiler kurması ve sürdürmesi elzemdir.

\section{KAYNAKÇA}

Berkes, N. (2019). Türkiye'de çağdaşlaşma. A. Kuyaş (Çev.), İstanbul: Yapı Kredi Yayınları.

Bilici, N. (2013). Avrupa birliği ve Türkiye. Ankara: Seçkin Yayıncılık.

Çalış. Ş. H. (2004). Türkiye-Avrupa birliği ilişskileri, kimlik arayışı politik aktörler ve değişim. Ankara: Nobel Yayın Dağıtım.

Erhan, Ç. ve Arat, T. (2009). “Avrupa Topluluklarıyla İlişkiler”, B. Oran (Ed.), Türk Dış Politikası, Kurtuluş Savaşı'ndan Bugüne Olgular, Belgeler, Yorumlar, içinde 83-101, İstanbul: İletişim Yayınları. 
Hatipler, M. (2011). "Türkiye-AB Gümrük Birliği Antlaşması ve Antlaşmanın Türkiye Ekonomisine Etkileri”, Trakya Üniversitesi Sosyal Bilimler Dergisi, Cilt. 13, Sayı. 1, 14 32 .

Hazine ve Maliye Bakanlığı, (2019). Ekonomik Göstergeler, https://www.hmb.gov.tr/ekonomikgostergeler, (Erişim Tarihi: 27.06.2019).

https://www.dw.com/tr/erdo\%C4\%9Fan-i\%C3\%A7imizde-bize-yanl\%C4\%B1\%C5\%9F-yapanlarvar/a-48513214 (Erişim Tarihi: 03.07.2019).

https://www.trthaber.com/haber/gundem/basbakan-erdogan-sanghay-isbirligi-teskilatina-turkiyeyialin-109567.html, (Erişim Tarihi: 03.07.2019).

https://www.bbc.com/turkce/haberler-dunya-38051013, (Erişim Tarihi: 03.07.2019).

https://www.ntv.com.tr/turkiye/bahceli-avrupa-birligi-kapisi-ardina-kadarkapandi,WQGYYRcGYE6nX5XMNhlWZg, (Erişim Tarihi: 04.07.2019).

Kılıç, R. (2005). Türkiye-AB ilişkileri ve gümrük birliği. Ankara: Siyasal Kitabevi.

Mardin, Ş. (2003). Türk modernleşmesi, makaleler 4. İstanbul: İletişim Yayınları.

Sandalcılar, A. R. ve Erdoğan, S. (2017). Ekonomik entegrasyonlar, Avrupa birliği ve Türkiye. Bursa: Ekin Basım Yayın Dağıtım.

Somel, S. A. (2010). Osmanlı'da eğitimin modernleşmesi (1839-1908), islamlaşma, otokrasi ve disiplin. O. Yener (Çev.), İstanbul: İletişim Yayınları.

Tecer, M. (2007). Avrupa birliği ve Türkiye, sorular-yanttlar. Ankara: Türkiye ve Ortadoğu Amme İdaresi Enstitüsü.

TÜiK, (2019a). Dış Ticaret İstatistikleri, Yıllara Göre Dış Ticaret, http://tuik.gov.tr/PreTablo.do?alt_id=1046, (Erişim Tarihi: 26.06.2019).

TÜIK, (2019b). Dış Ticaret İstatistikleri, Coğrafi Ülke Gruplarına Göre Dış Ticaret, https://biruni.tuik.gov.tr/disticaretapp/disticaret.zul?param1=5\&param2=0\&sitcrev=0\&isic rev $=0 \&$ sayac $=5809$, (Erişim Tarihi: 26.06.2019).

TÜIK, (2019c). Dış Ticaret İstatistikleri, Coğrafi Ülke Grupları ve Fasıllara Göre Dış Ticaret, https://biruni.tuik.gov.tr/disticaretapp/disticaret.zul?param1=5\&param2=21\&sitcrev=0\&isi $\mathrm{crev}=0 \&$ sayac $=5809$, (Erişim Tarihi: 03.07.2019).

Ülger, U. (2017). “Siyasal İslam’ın AB’ye Bakış Açısı: Milli Görüş Hareketi Örneği”, Süleyman Demirel Üniversitesi, Sosyal Bilimler Enstitüsü Dergisi, Sayı. 29, 619-632.

WB, (2019). World Development Indicators, https://databank.worldbank.org/source/worlddevelopment-indicators, (Erişim Tarihi: 28.06.2019).

Zurcher, E. J. (2018). Modernleşen Türkiye’nin tarihi. Y. Gönen (Çev.), İstanbul: İletişim Yayınları. 